\title{
Elucidation of Antioxidant Compounds in Moroccan Chamaerops humilis L. Fruits by GC-MS and HPLC-MS Techniques
}

\author{
Hafssa El Cadi ${ }^{1}$ (), Hajar El Bouzidi 1,2, Ginane Selama ${ }^{2}$, Btissam Ramdan ${ }^{3}$, Yassine Oulad El Majdoub ${ }^{4}$, \\ Filippo Alibrando $\left.{ }^{5}{ }^{(}\right)$, Katia Arena ${ }^{4}$, Miguel Palma Lovillo ${ }^{6}{ }^{(}$, Jamal Brigui ${ }^{1}$, Luigi Mondello ${ }^{4,5,7,8} \mathbb{D}$, \\ Francesco Cacciola ${ }^{9, *(\mathbb{O})}$ and Tania M. G. Salerno ${ }^{8}$
}

check for updates

Citation: Cadi, H.E.; Bouzidi, H.E. Selama, G.; Ramdan, B.; Majdoub, Y.O.E.; Alibrando, F.; Arena, K.; Lovillo, M.P.; Brigui, J.; Mondello, L.; et al. Elucidation of Antioxidant Compounds in Moroccan Chamaerops humilis L. Fruits by GC-MS and HPLC-MS Techniques. Molecules 2021, 26, 2710. https://doi.org/ $10.3390 /$ molecules 26092710

Academic Editor: Mirella Nardini

Received: 8 April 2021

Accepted: 3 May 2021

Published: 5 May 2021

Publisher's Note: MDPI stays neutral with regard to jurisdictional claims in published maps and institutional affiliations.

Copyright: (c) 2021 by the authors. Licensee MDPI, Basel, Switzerland This article is an open access article distributed under the terms and conditions of the Creative Commons Attribution (CC BY) license (https:// creativecommons.org/licenses/by/ $4.0 /)$.
1 Laboratory of Valorization of Resources and Chemical Engineering, Department of Chemistry, Abdelmalek Essaadi University, Tangier 90000, Morocco; hafssa.elcadi@yahoo.fr (H.E.C.); hajarelbouzidi1995@gmail.com (H.E.B.); jamalbrigui@yahoo.fr (J.B.)

2 Laboratory of Biochemistry and Molecular Genetics, Abdelmalek Essaadi University, Tangier 90000, Morocco; ginane.selama@gmail.com

3 Department of Biology, Laboratory of Biotechnology and Valorization of Natural Resources, Faculty of Science, University Ibn Zohr, Agadir 80000, Morocco; ramdanbtissam8@gmail.com

4 Department of Chemical, Biological, Pharmaceutical and Environmental Sciences, University of Messina, 98168 Messina, Italy; youladelmajdoub@unime.it (Y.O.E.M.); arenak@unime.it (K.A.); lmondello@unime.it (L.M.)

5 Chromaleont s.r.l., c/o Department of Chemical, Biological, Pharmaceutical and Environmental Sciences, University of Messina, 98168 Messina, Italy; filippo.alibrando@chromaleont.it

6 Department of Analytical Chemistry, Faculty of Sciences, Agrifood Campus of International Excellence (ceiA3), University of Cadiz, IVAGRO, 11510 Cadiz, Spain; miguel.palma@uca.es

7 Department of Sciences and Technologies for Human and Environment, University Campus Bio-Medico of Rome, 00128 Rome, Italy

8 BeSep s.r.l., c/o Department of Chemical, Biological, Pharmaceutical and Environmental Sciences, University of Messina, 98168 Messina, Italy; tania.salerno@besep.it

9 Department of Biomedical, Dental, Morphological and Functional Imaging Sciences, University of Messina, 98125 Messina, Italy

* Correspondence: cacciolaf@unime.it; Tel.: +39-090-676-6570

Abstract: The aim of this study was to characterize the phytochemical content as well as the antioxidant ability of the Moroccan species Chamaerops humilis L. Besides crude ethanolic extract, two extracts obtained by sonication using two solvents with increased polarity, namely ethyl acetate (EtOAc) and methanol-water (MeOH-H $\left.{ }_{2} \mathrm{O}\right)$ 80:20 ( $\left.v / v\right)$, were investigated by both spectroscopy and chromatography methods. Between the two extracts, the $\mathrm{MeOH}-\mathrm{H}_{2} \mathrm{O}$ one showed the highest total polyphenolic content equal to $32.7 \pm 0.1 \mathrm{mg}$ GAE/g DM with respect to the EtOAc extract $(3.6 \pm 0.5 \mathrm{mg} \mathrm{GAE} / \mathrm{g} \mathrm{DM})$. Concerning the antioxidant activity of the two extracts, the EtOAc one yielded the highest value $(1.9 \pm 0.1 \mathrm{mg} / \mathrm{mL})$ with respect to $\mathrm{MeOH}-\mathrm{H} 2 \mathrm{O}(0.4 \pm 0.1 \mathrm{mg} / \mathrm{mL})$. The C. humilis $n$-hexane fraction, analyzed by GC-MS, exhibited 69 compounds belonging to different chemical classes, with $n$-Hexadecanoic acid as a major compound $(21.75 \%)$, whereas the polyphenolic profile, elucidated by HPLC-PDA/MS, led to the identification of a total of sixteen and thirteen different compounds in both EtOAc (major component: ferulic acid: $104.7 \pm 2.52 \mu \mathrm{g} / \mathrm{g}$ ) and $\mathrm{MeOH}-$ $\mathrm{H}_{2} \mathrm{O}$ extracts (major component: chlorogenic acid: $45.4 \pm 1.59 \mu \mathrm{g} / \mathrm{g}$ ), respectively. The attained results clearly highlight the potential of $C$. humilis as an important source of bioactive components, making it a valuable candidate to be advantageously added to the daily diet. Furthermore, this study provides the scientific basis for the exploitation of the Doum in the food, pharmaceutical and nutraceutical industries.

Keywords: Arecaceae; polyphenols; volatile content; antioxidant activity; liquid chromatography 


\section{Introduction}

The Moroccan wild palm tree (Chamaerops humilis L.), widely called "Doum", is found in six cities of the eastern region of Morocco, namely Oujda, Berkane, Ahfir, Saidia, Nador and Jerrada [1], and represents $7.74 \%$ of the total number of Moroccan palm trees [2].

Such a species is cultivated in many Mediterranean countries as an ornament, considering its robustness and decorative features.

Some components of this plant have been used as food as an important source of nutritional energy [3], or in traditional medicine. The husks are eaten in Southern Spain, the fruits in Morocco and the young suckers in Italy. Leaf extracts of Chamaerops humilis L. (C. humilis) have been commonly used for the treatment of diabetes, digestive disorders, spasms, tone and gastrointestinal disorders [4,5]. Moreover, their fruits have astringent properties thanks to their tannin content, even though, in Morocco, they have been rarely consumed due to their bitter taste [4].

Other studies have shown the beneficial effects of these fruits against hyperlipidemia in an animal model of obesity and hyperglycemia [6]. Thanks to their sedative action, they have been also used to treat insomnia, cough attacks and bronchitis [7]; also, the "Doum" has shown anti-inflammatory, anabolic, antiseptic, urinary, antilithic and diuretic activities $[4,7,8]$. Leaf extracts have also been reported to possess antioxidant activity and the ability to inhibit lipoxygenase $[9,10]$.

The phytochemical properties of $C$. humilis are so far only little characterized. The analysis of the grain's oil showed higher levels of oleic and linoleic acids than other seed oils, as well as a significant amount of tocopherols and tocotrienols [11].

Several biologically important secondary metabolites such as flavonoids, phenols, saponins, gallic tannins and terpenoids have been detected in the leaves and fruits of C. humilis L., which may explain the pharmacological effects mentioned above $[4,7,9,12]$.

With regard to flavonoids, they have been previously reported as constituents of the Arecaceae family of plants, even though the literature lacks detailed information on the phytochemical composition of $C$. humilis. Further, no work has been so far devoted to the analysis of the volatile content of such a species.

The aim of this work was to determine the volatile and polyphenolic content of Moroccan Doum fruits (C. humilis L.) by GC-MS and HPLC-PDA/MS. In addition, the evaluation of the physico-chemical properties, and the antioxidant activities of the fruit extracts, was performed as well.

This study represents an effort to provide more reliable information about the antioxidant and beneficial health properties of such a species in order to promote its use in different food, pharmaceutical and supplement industries.

\section{Results and Discussion}

\subsection{Physico-Chemical Parameters}

Table 1 reports the physico-chemical parameters for the C. humilis fruit under investigation.

Table 1. Physico-chemical parameters of $C$. humilis fruit samples. The results are expressed as mean \pm standard deviation.

\begin{tabular}{cccr}
\hline \multirow{2}{*}{ Fruit } & Crude Extract & \multicolumn{2}{c}{ Solvent Fractions } \\
\cline { 3 - 4 } & & EtOAc & $\mathbf{M e O H}_{\mathbf{2}} \mathbf{O}$ \\
\hline pH & $3.0 \pm 0.06$ & - & - \\
\hline Acidity & $1.5 \pm 0.28$ & - & $1.3 \pm 0.00$ \\
\hline RI & $1.4 \pm 0.10$ & $1.3 \pm 0.00$ & $3.0 \pm 0.01$ \\
\hline TSS & $15.2 \pm 0.68$ & $0.4 \pm 0.01$ & - \\
\hline S/A & $10.3 \pm 0.5$ & - & - \\
\hline DM (\%) & $69.5 \pm 0.51$ & - & - \\
\hline Ash (\%) & $3.0 \pm 0.31$ & - & -
\end{tabular}


Table 1. Cont.

\begin{tabular}{cccr}
\hline \multirow{2}{*}{ Fruit } & Crude Extract & \multicolumn{2}{c}{ Solvent Fractions } \\
\cline { 3 - 4 } & & EtOAc & MeOH-H $_{\mathbf{2}} \mathbf{O}^{-}$ \\
\hline TS (\%) & $23.7 \pm 0.86$ & $6.4 \pm 0.05$ & $4.6 \pm 0.10$ \\
\hline RS (\%) & $18.1 \pm 0.72$ & - & - \\
\hline Lipids(mg/g) & $0.70 \pm 0.05$ & - & $0.6 \pm 0.01$ \\
\hline Proteins(mg/g) & $5.33 \pm 1.5$ & $13.6 \pm 0.45$ & $30 \pm 0.28$ \\
\hline Vitamin C (mg/g) & $31.4 \pm 0.53$ & - & - \\
\hline
\end{tabular}

RI: refractive index; TSS: total soluble solid ( ${ }^{\circ}$ Brix); DM: dry matter; S/A: sugar/acidity; TS: total sugars; RS: reducing sugars.

The percentage of dry matter attained was equal to $69.6 \pm 0.5$, approximately indicating the presence of $30.4 \%$ water in these fruits. The latter value is twice as high than the one reported by Bouhafsoun et al. (17.4 $\pm 0.12 \%)$ [2]. On the other hand, another study showed a higher value $(79.6 \pm 0.04 \%)$ in Butia odorata, which belongs to the same family (Arecaceae) [13].

The ash content revealed interesting amounts of minerals $(3.0 \pm 0.3)$. Such a value coincides with the mean value of ash content (2.4 to 5.0\%) recommended by FAO [14], even though it is lower than that recently reported for the Algerian species $(4.2 \pm 0.7 \%)$ [2].

Concerning the $\mathrm{pH}$ measurement, a value of $3 \pm 0.06$ was attained. This value is lower than the one found by Bouhafsoun et al. (5.0 \pm 0.0$)$ [2] and, in general, other species belonging to the Arecaceae family, e.g., date palm (Phoenix dactylifera L.) (5.3 \pm 0.0$)$ [15] and doum palm (Hyphaene thebaica) $(4.8 \pm 0.0)$ [16].

The titratable acidity of $C$. humilis L. fruit revealed a percentage of $1.5 \pm 0.3 \%$. This value is slightly different from Algerian fruits $(0.2 \pm 0.0 \%)$ [2], but similar to other species, e.g., Hyphaene thebaica (0.22\%) [16].

The TSS results showed a mean value of $15.2 \pm 0.7 \%$. Similar values were found in Butia odorata fruits (13.1-14.6\%) [17], despite Ferrão et al. (2013) revealing, for the same species, a value of $9.5 \pm 0.0 \%$ [13]. These results are not in agreement with other studies where values reported were $2.4 \%$ in leaves and rachis and $4 \%$ in fruits [2]. This can be directly related to the sugar content of the fruit samples, which have higher sugar content than other parts of $C$. humilis L. [2].

The S/A ratio was $10.3 \pm 0.5 \%$. Such a ratio is an important biochemical parameter that influences the taste and acceptability of the fruits. The high values of this ratio indicate good technological properties and consumer acceptance of these fruits $[18,19]$. The result achieved in this study falls within the range found for Butia odorata fruits (4.42-14.20\%) [13]. On the other hand, the S/A ratio values of the C. humulis L. fruits investigated in this work showed higher values compared to those of B. capitata reported in the literature, $4.7-5.8 \%$ [20].

Results of RS and TS were equal to $18.1 \pm 0.7 \%$ and $23.7 \pm 0.9 \%$, respectively. Vitamin C contents in Doum extracts were determined to be $31.5 \pm 0.5 \mathrm{mg} / \mathrm{g}$, which is slightly higher than other research $(20.1 \pm 0.5 \mathrm{mg} / \mathrm{g})$ [21].

The refractive index values for the $C$. humilis $\mathrm{L}$. in each extract were $1.3 \pm 0.0$ and $1.34 \pm$ 0.0 for ethyl acetate $(\mathrm{EtOAc})$ and methanol-water $\left(\mathrm{MeOH}-\mathrm{H}_{2} \mathrm{O}\right)$, respectively. The ANOVA test $(p>0.05)$ showed that the difference between the fruits in IR was not significant.

With regard to lipid and protein contents, values of $0.7 \pm 0.0 \%$ and $5.3 \pm 1.5 \%$ were attained, respectively. A value of $0.6 \pm 0.0 \mathrm{mg} / \mathrm{g}$ was attained for the $\mathrm{MeOH}-\mathrm{H}_{2} \mathrm{O}$ extract, whereas they were absent in the EtOAc fraction. The low levels of protein content can be caused by the ultrasonic extraction, which leads to protein denaturation, as proven by some researchers [22]. 


\subsection{Phytochemical Screening}

The phytochemical screening of $C$. humilis was carried out, for the first time for a Moroccan species. The phytochemical tests revealed the presence of different chemical families, distributed for the studied species according to the solvent concentration used. Anthocyanins were not detected in any of the samples investigated. In the EtOAc extract, unsaturated sterols, terpenes and glycosides, which were absent in the crude extract, were revealed. On the other hand, in the crude extract, catechic tannins, anthracenosides, sterols and steroids were detected in high concentrations.

In the literature, the phytochemical properties of C. humilis are not well characterized, although several studies have reported the presence of tannins, flavonoids, saponins, sterols and terpenoids [10]. These results are similar to those found in samples from Algeria [23]. Notably, saponosides, responsible for many pharmacological properties, e.g., anti-inflammatory $[24,25]$, were also detected in the extract of $C$. humilis. From the results achieved, such a species does contain important phytochemical constituents that may contribute to its anti-inflammatory and antioxidant activities (Table 2).

Table 2. Phytochemical screening of $C$. humilis samples.

\begin{tabular}{|c|c|c|c|c|}
\hline \multicolumn{2}{|c|}{ Compounds Group/Solvent of Extraction } & Crude Extract & EtOAc & $\mathrm{MeOH}-\mathrm{H}_{2} \mathrm{O}$ \\
\hline \multicolumn{2}{|c|}{ Alkaloids } & + & + & \pm \\
\hline \multirow{9}{*}{ Polyphenols } & Flavonoids & $\mathrm{B}$ & B & $\mathrm{A}++$ \\
\hline & Tannins & + & + & + \\
\hline & Anthocyanins & - & - & - \\
\hline & Catechic tannins & ++ & - & + \\
\hline & Gallic tannins & - & - & + \\
\hline & Coumarins & + & + & + \\
\hline & Anthracenosides & ++ & - & - \\
\hline & Anthraquinones & + & - & - \\
\hline & $\begin{array}{c}\text { Anthracenosides and } \\
\text { Anthocyanosides }\end{array}$ & + & - & - \\
\hline \multirow{3}{*}{ Steroids } & Saponosides & ++ & - & - \\
\hline & $\begin{array}{c}\text { Unsaturated } \\
\text { Sterols/Terpenes }\end{array}$ & - & + & - \\
\hline & Sterols and Steroids & ++ & - & - \\
\hline \multirow{4}{*}{ Sugars } & Starch & + & - & - \\
\hline & Deoxysugars & + & - & - \\
\hline & Glycosides & - & + & \pm \\
\hline & Mucilages & + & - & + \\
\hline
\end{tabular}

A: Flavones; B: Isoflavones; ++: Abondant; +: Present; -: Absent.

\subsection{Phytochemical Content and Antioxidant Ability}

The spectrophotometric assays showed an important amount of polyphenols. Comparing the two extracts, the $\mathrm{MeOH}-\mathrm{H}_{2} \mathrm{O}$ one showed the highest total polyphenolic (TPP) content, equal to $32.7 \pm 0.1 \mathrm{mg} \mathrm{GAE} / \mathrm{g}$ DM, with respect to the EtOAc extract, $3.6 \pm 0.5 \mathrm{mg}$ GAE/g DM (Table 3). The same considerations can be made for the total flavonoid (TFv) and total tannin (TT) contents.

Table 3. TPP, TFv and TT content in C. humilis solvent fractions.

\begin{tabular}{ccccc}
\hline Extract & TPP & TFv & TT & IC $_{\mathbf{5 0}}$ \\
\hline EtOAc & $3.6 \pm 0.5$ & $6.5 \pm 0.1$ & $6.2 \pm 0.5$ & $1.9 \pm 0.1$ \\
\hline $\mathbf{M e O H}_{-} \mathbf{H}_{\mathbf{2}} \mathbf{O}$ & $32.7 \pm 0.1$ & $11.1 \pm 0.45$ & $54.3 \pm 0.8$ & $0.4 \pm 0.1$ \\
\hline
\end{tabular}


Statistical analysis (ANOVA) showed that there was a highly significant difference in results $(p<0.001)$ between the different solvent concentrations, thus indicating an effect of the solvent concentration on the extraction of these compounds [26].

Concerning the antioxidant activity of the two fractions $(1.9 \pm 0.1 \mathrm{mg} / \mathrm{mL}$ and $0.4 \pm 0.1 \mathrm{mg} / \mathrm{mL}$, respectively, for EtOAc and $\mathrm{MeOH}-\mathrm{H}_{2} \mathrm{O}$ ), the values attained are higher than those found by other authors, e.g., Belhaoues et al. (2017) [27] and Gonçalves et al. (2018) [10] $(0.12 \mathrm{mg} / \mathrm{mL}$ and $0.081 \mathrm{mg} / \mathrm{mL})$. Another two studies obtained from a methanolic extract of $C$. humilis reported $\mathrm{IC}_{50}$ values of $0.024 \mathrm{mg} / \mathrm{mL}$ [28] and $0.455 \mathrm{mg} / \mathrm{mL}$ [29]. Our findings are in agreement with previously reported papers on different species [26,30].

\subsection{GC-MS Analyses}

The C. humilis $n$-hexane fraction exhibited 69 compounds belonging to different chemical classes (Figure 1). Similarity ranged from $87 \%$ to $96 \%$. The main volatile compound was represented by $n$-Hexadecanoic acid (21.75\%), followed by oleic acid (14.66\%) (Table 4$)$. Such findings are consistent with other C. humilis works [31,32].

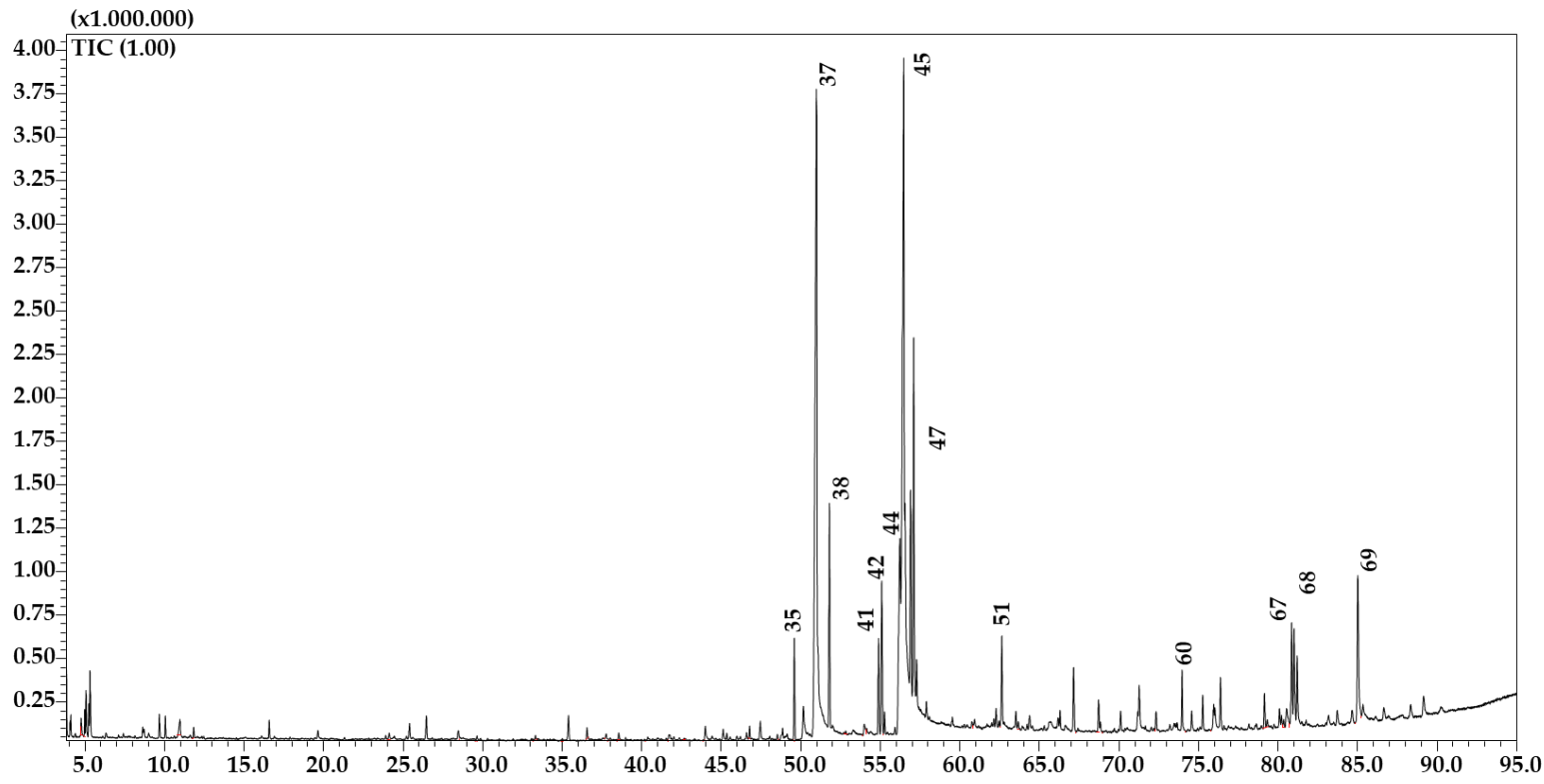

Figure 1. GC-MS profile of the $n$-hexane fraction of $C$. humilis. Main peaks are labeled. Peak assignment as in Table 4.

Table 4. List of compounds identified in the $n$-hexane fraction of C. humilis by GC-MS.

\begin{tabular}{|c|c|c|c|c|c|c|}
\hline No. & Compound & LRI (lib) & LRI (exp) & Similarity & Area(\%) & Library \\
\hline 1 & $n$-Hexanol & 867 & 867 & 90 & 0.04 & FFNSC 4.0 \\
\hline 2 & Acetonylacetone & 923 & 925 & 90 & 0.11 & FFNSC 4.0 \\
\hline 3 & $n$-Hexanoic acid & 997 & 977 & 96 & 0.31 & FFNSC 4.0 \\
\hline 4 & $n$-Nonanal & 1107 & 1106 & 96 & 0.27 & FFNSC 4.0 \\
\hline 5 & n-Octanoic acid & 1192 & 1171 & 94 & 0.19 & FFNSC 4.0 \\
\hline 6 & $n$-Decanal & 1208 & 1207 & 91 & 0.06 & FFNSC 4.0 \\
\hline 7 & (2E)-Decenal & 1265 & 1264 & 92 & 0.06 & FFNSC 4.0 \\
\hline 8 & Nonanoic acid & 1289 & 1269 & 92 & 0.13 & FFNSC 4.0 \\
\hline 9 & (2E,4E)-Decadienal & 1322 & 1296 & 93 & 0.41 & FFNSC 4.0 \\
\hline 10 & $n$-Decanoic acid & 1398 & 1366 & 93 & 0.15 & FFNSC 4.0 \\
\hline 11 & ethyl-Decanoate & 1399 & 1395 & 93 & 0.08 & FFNSC 4.0 \\
\hline 12 & (E)-, $\beta$-Ionone & 1482 & 1482 & 87 & 0.07 & FFNSC 4.0 \\
\hline 13 & $\begin{array}{l}\text { methyl-Dodecanoate } \\
5,6,7,7 a-t e t r a h y d r o-\end{array}$ & 1527 & 1524 & 88 & 0.03 & FFNSC 4.0 \\
\hline 14 & $\begin{array}{l}\text { 4,4,7a-trimethyl-,(R)- } \\
\text { 2(4H)-Benzofuranone }\end{array}$ & 1532 & 1533 & 90 & 0.46 & W11N17 \\
\hline
\end{tabular}


Table 4. Cont.

\begin{tabular}{|c|c|c|c|c|c|c|}
\hline No. & Compound & LRI (lib) & LRI (exp) & Similarity & Area(\%) & Library \\
\hline 15 & n-Dodecanoic acid & 1581 & 1563 & 94 & 0.18 & FFNSC 4.0 \\
\hline 16 & ethyl-Dodecanoate & 1598 & 1594 & 89 & 0.11 & FFNSC 4.0 \\
\hline 17 & n-Hexadecane & 1600 & 1600 & 87 & 0.03 & FFNSC 4.0 \\
\hline 18 & n-Tetradecanal & 1614 & 1614 & 91 & 0.13 & FFNSC 4.0 \\
\hline 19 & 1.1'-oxybis-Octane & 1657 & 1663 & 88 & 0.10 & W11N17 \\
\hline 20 & n-Heptadecane & 1700 & 1700 & 90 & 0.17 & FFNSC 4.0 \\
\hline 21 & 2-Pentadecanol & 1710 & 1707 & 92 & 0.05 & W11N17 \\
\hline 22 & Pentadecanal & 1717 & 1716 & 90 & 0.08 & W11N17 \\
\hline 23 & methyl-Tetradecanoate & 1727 & 1725 & 87 & 0.03 & FFNSC 4.0 \\
\hline 24 & n-Tetradecanoic acid & 1773 & 1762 & 87 & 0.23 & FFNSC 4.0 \\
\hline 25 & ethyl-Tetradecanoate & 1794 & 1793 & 93 & 0.22 & FFNSC 4.0 \\
\hline 26 & n-Octadecane & 1800 & 1800 & 91 & 0.09 & FFNSC 4.0 \\
\hline 27 & Hexadecanal & 1820 & 1818 & 93 & 0.09 & W11N17 \\
\hline 28 & $\begin{array}{l}\text { Pentadecanoic acid, } \\
\text { methyl ester }\end{array}$ & 1824 & 1825 & 88 & 0.11 & W11N17 \\
\hline 29 & Neophytadiene & 1836 & 1836 & 92 & 0.10 & FFNSC 4.0 \\
\hline 30 & Phytone & 1841 & 1842 & 94 & 0.19 & FFNSC 4.0 \\
\hline 31 & Pentadecylic acid & 1869 & 1863 & 90 & 0.11 & FFNSC 4.0 \\
\hline 32 & ethyl-Pentadecanoate & 1893 & 1893 & 91 & 0.09 & FFNSC 4.0 \\
\hline 33 & n-Nonadecane & 1900 & 1900 & 90 & 0.13 & FFNSC 4.0 \\
\hline 34 & $\begin{array}{l}\text { (Z)-9-Hexadecenoic } \\
\text { acid, methyl ester }\end{array}$ & 1895 & 1903 & 93 & 0.14 & W11N17 \\
\hline 35 & methyl-Hexadecanoate & 1925 & 1926 & 95 & 1.62 & FFNSC 4.0 \\
\hline 36 & Hexadecanolact-16-one & 1938 & 1943 & 88 & 0.77 & FFNSC 4.0 \\
\hline 37 & n-Hexadecanoic acid & 1977 & 1969 & 94 & 21.75 & FFNSC 4.0 \\
\hline 38 & ethyl-Palmitate & 1993 & 1993 & 96 & 3.80 & FFNSC 4.0 \\
\hline 39 & $\begin{array}{l}\text { Heptadecanoic acid, } \\
\text { methyl ester }\end{array}$ & 2028 & 2026 & 90 & 0.06 & W11N17 \\
\hline 40 & Heptadecanoic acid & 2080 & 2064 & 94 & 0.33 & W11N17 \\
\hline 41 & methyl-Linoleate & 2093 & 2093 & 90 & 1.57 & FFNSC 4.0 \\
\hline 42 & methyl-Oleate & 2098 & 2098 & 92 & 2.61 & FFNSC 4.0 \\
\hline 43 & methyl-Octadecanoate & 2127 & 2127 & 89 & 0.11 & FFNSC 4.0 \\
\hline 44 & Linoleic acid & 2144 & 2137 & 92 & 6.90 & FFNSC 4.0 \\
\hline 45 & Oleic acid & 2142 & 2145 & 89 & 14.66 & FFNSC 4.0 \\
\hline 46 & (Z)-Vaccenic acid & 2161 & 2148 & 92 & 4.03 & W11N17 \\
\hline 47 & ethyl-Linoleate & 2164 & 2160 & 92 & 5.04 & FFNSC 4.0 \\
\hline 48 & $\begin{array}{l}\text { (E)-9-Octadecenoic } \\
\text { acid ethyl ester }\end{array}$ & 2174 & 2173 & 92 & 2.10 & W11N17 \\
\hline 49 & ethyl-Stearate & 2198 & 2194 & 91 & 0.53 & FFNSC 4.0 \\
\hline 50 & n-Tricosane & 2300 & 2300 & 90 & 0.22 & FFNSC 4.0 \\
\hline 51 & (Z)-9-Octadecenamide & 2375 & 2362 & 94 & 1.69 & W11N17 \\
\hline 52 & n-Tetracosane & 2400 & 2400 & 88 & 0.12 & FFNSC 4.0 \\
\hline 53 & Behenyl alcohol & 2493 & 2495 & 89 & 0.19 & FFNSC 4.0 \\
\hline 54 & n-Pentacosane & 2500 & 2500 & 93 & 0.31 & FFNSC 4.0 \\
\hline 55 & 1-Hexacosene & 2596 & 2595 & 90 & 0.54 & W11N17 \\
\hline 56 & n-Hexacosane & 2600 & 2599 & 93 & 0.19 & FFNSC 4.0 \\
\hline 57 & Heptacos-1-ene & 2694 & 2695 & 89 & 0.33 & W11N17 \\
\hline 58 & n-Heptacosane & 2700 & 2700 & 92 & 0.88 & FFNSC 4.0 \\
\hline 59 & n-Octacosane & 2800 & 2799 & 89 & 0.16 & FFNSC 4.0 \\
\hline 60 & Squalene & 2810 & 2813 & 94 & 1.15 & FFNSC 4.0 \\
\hline 61 & Hexacosanal & 2833 & 2840 & 93 & 0.41 & W11N17 \\
\hline 62 & n-Nonacosane & 2900 & 2900 & 90 & 0.50 & FFNSC 4.0 \\
\hline 63 & Octacosanal & 3039 & 3044 & 95 & 0.65 & W11N17 \\
\hline 64 & $\gamma$-Tocopherol & 3055 & 3053 & 88 & 0.15 & W11N17 \\
\hline 65 & $n$-Hentriacontane & 3100 & 3100 & 92 & 0.13 & FFNSC 4.0 \\
\hline 66 & Octacosanol & 3120 & 3109 & 94 & 0.68 & W11N17 \\
\hline 67 & 2-Nonacosanone & 3125 & 3123 & 91 & 2.16 & W11N17 \\
\hline 68 & Vitamin E & 3130 & 3131 & 93 & 2.07 & W11N17 \\
\hline \multirow[t]{3}{*}{69} & $\gamma$-Sitosterol & 3351 & 3321 & 90 & 4.13 & W11N17 \\
\hline & Tot. identified & & & & 87.29 & \\
\hline & Tot. not identified & & & & 12.71 & \\
\hline
\end{tabular}




\subsection{HPLC-PDA/MS Analyses}

The analysis of the polyphenolic profile, achieved by HPLC-PDA of the EtOAc and $\mathrm{MeOH}-\mathrm{H}_{2} \mathrm{O}$ extracts of $\mathrm{C}$. humilis, is reported in Figure 2. A total of sixteen and thirteen different polyphenolic compounds were detected in both extracts, respectively. Tentative identification was based on combined data coming from retention times, PDA, MS and standard co-injection, when available (thirteen in EtOAc vs. twelve in $\mathrm{MeOH}-\mathrm{H}_{2} \mathrm{O}$ extracts (Tables 5 and 6)). Interestingly, the totality of the polyphenolic compounds in both extracts belong to the hydroxycinnamic acids class, whereas only two flavonols were identified in both extracts. Most of the compounds were already reported as constituents of fruits of botanical species, belonging to the same family, e.g., ferulic acid, feruloylquinic acid, ferulic acid hexoside [33], $p$-Coumaric acid, dicaffeoylshikimic acid and isorhamnetindiglucoside [34]. Notably, 3-Caffeoylquinic acid and 3-Caffeoylquinic acid were reported as constituents of leaf extracts of $C$. humilis [10], whereas quinic acid, $p$-Coumaric, rutin and kaempferol were found in the fruits of the same species [23]. Cinnamoyl glucose and $p$-Coumaric acid ethyl ester are here reported for the first time.
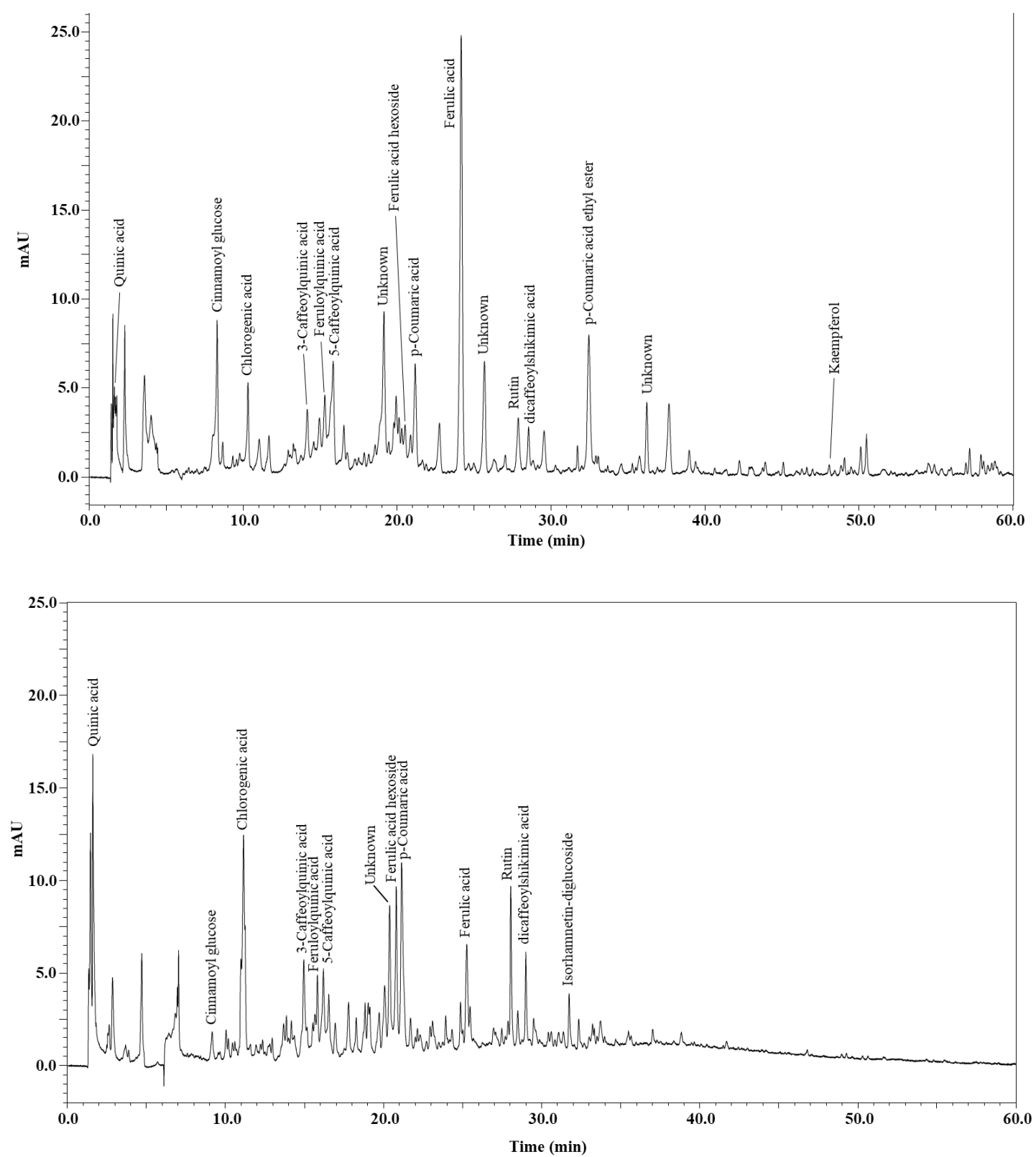

Figure 2. HPLC-PDA polyphenolic profile of the EtOAc (top) and $\mathrm{MeOH}-\mathrm{H}_{2} \mathrm{O}$ extracts of $C$. humilis. 
Table 5. Polyphenolic compounds detected in EtOAc extract of C. humilis by HPLC-PDA-ESI/MS.

\begin{tabular}{|c|c|c|c|c|c|}
\hline Tentative Identification & $t_{R}(\min )$ & Identification Type & $\begin{array}{c}\lambda_{\text {MAX }} \\
(\mathrm{nm})\end{array}$ & {$[\mathrm{M}-\mathrm{H}]^{-}$} & Fragments \\
\hline \multicolumn{6}{|c|}{ Phenolic Acid and Derivatives } \\
\hline Quinic acid & 1.64 & $\mathrm{PDA} / \mathrm{MS}$ & - & 191 & - \\
\hline Cinnamoyl glucose & 8.31 & $\mathrm{PDA} / \mathrm{MS}$ & $258-291$ & 309 & - \\
\hline Chlorogenic acid & 10.31 & $\mathrm{PDA} / \mathrm{MS}$ & 324 & 353 & 179 \\
\hline 3-Caffeoylquinic acid & 14.15 & $\mathrm{PDA} / \mathrm{MS}$ & 321 & 353 & - \\
\hline Feruloylquinic acid & 15.29 & $\mathrm{PDA} / \mathrm{MS}$ & 324 & 367 & - \\
\hline 5-Caffeoylquinic acid & 15.83 & $\mathrm{PDA} / \mathrm{MS}$ & $213-324$ & 353 & 179 \\
\hline Unknown & 19.13 & $\mathrm{PDA} / \mathrm{MS}$ & $282-325$ & 336 & - \\
\hline Ferulic acid hexoside & 20.51 & $\mathrm{PDA} / \mathrm{MS}$ & $214-324$ & 355 & 191 \\
\hline p-coumaric acid & 22.74 & $\mathrm{PDA} / \mathrm{MS}$ & 288 & 163 & - \\
\hline Ferulic acid & 24.16 & $\mathrm{PDA} / \mathrm{MS}$ & $216-321$ & 193 & - \\
\hline Unknown & 25.66 & PDA/MS & 304 & 193 & - \\
\hline dicaffeoylshikimic acid & 28.54 & $\mathrm{PDA} / \mathrm{MS}$ & $217-291$ & 497 & 179 \\
\hline p-Coumaric acid ethyl ester & 32.46 & $\mathrm{PDA} / \mathrm{MS}$ & $247-291$ & 191 & - \\
\hline Unknown & 36.22 & PDA/MS & 270 & 345 & 263 \\
\hline \multicolumn{6}{|c|}{ Flavonols } \\
\hline Rutin & 27.86 & $\mathrm{PDA} / \mathrm{MS}$ & 352 & 609 & - \\
\hline Kaempferol & 48.18 & $\mathrm{PDA} / \mathrm{MS}$ & $219-369$ & 285 & - \\
\hline
\end{tabular}

Table 6. Polyphenolic compounds detected in $\mathrm{MeOH}-\mathrm{H}_{2} \mathrm{O}$ extract of $\mathrm{C}$. humilis by HPLC-PDA-ESI/MS.

\begin{tabular}{|c|c|c|c|c|c|}
\hline Tentative Identification & $\underset{(\mathrm{min})}{\mathrm{t}_{\mathrm{R}}}$ & Identification Type & $\begin{array}{c}\lambda_{\mathrm{MAX}} \\
(\mathrm{nm})\end{array}$ & {$[\mathbf{M}-\mathrm{H}]^{-}$} & Fragments \\
\hline \multicolumn{6}{|c|}{ Phenolic Acid and Derivatives } \\
\hline Quinic acid & 1.64 & $\mathrm{PDA} / \mathrm{MS}$ & - & 191 & - \\
\hline Cinnamoyl glucose & 8.31 & $\mathrm{PDA} / \mathrm{MS}$ & $258-291$ & 309 & - \\
\hline Chlorogenic acid & 10.31 & $\mathrm{PDA} / \mathrm{MS}$ & 324 & 353 & 179 \\
\hline 3-Caffeoylquinic acid & 14.15 & $\mathrm{PDA} / \mathrm{MS}$ & 321 & 353 & - \\
\hline Feruloylquinic acid & 15.29 & $\mathrm{PDA} / \mathrm{MS}$ & 324 & 367 & - \\
\hline 5-Caffeoylquinic acid & 15.83 & $\mathrm{PDA} / \mathrm{MS}$ & $213-324$ & 353 & 179 \\
\hline Unknown & 19.13 & $\mathrm{PDA} / \mathrm{MS}$ & $282-325$ & 336 & - \\
\hline Ferulic acid hexoside & 20.51 & $\mathrm{PDA} / \mathrm{MS}$ & $214-324$ & 355 & 191 \\
\hline p-coumaric acid & 22.74 & $\mathrm{PDA} / \mathrm{MS}$ & 288 & 163 & - \\
\hline Ferulic acid & 24.16 & $\mathrm{PDA} / \mathrm{MS}$ & $216-321$ & 193 & - \\
\hline Dicaffeoylshikimic acid & 28.54 & $\mathrm{PDA} / \mathrm{MS}$ & $217-291$ & 497 & 179 \\
\hline \multicolumn{6}{|c|}{ Flavonols } \\
\hline Rutin & 27.86 & $\mathrm{PDA} / \mathrm{MS}$ & 352 & 609 & - \\
\hline Isorhamnetin-diglucoside & 31.75 & $\mathrm{PDA} / \mathrm{MS}$ & 353 & 623 & - \\
\hline
\end{tabular}

The quantification was determined for three repetitions of different extracts of the same sample. As far as quantification is concerned (Table 7), ferulic acid in the EtOAc extract turned out to be the most abundant one $(104.7 \mu \mathrm{g} / \mathrm{g})$, followed by 5-Caffeoylquinic acid $(36.5 \mu \mathrm{g} / \mathrm{g})$. On the other hand, in the $\mathrm{MeOH}-\mathrm{H}_{2} \mathrm{O}$ extract, chlorogenic acid $(45.4 \mu \mathrm{g} / \mathrm{g})$ was predominant, along with quinic acid $(37.0 \mu \mathrm{g} / \mathrm{g})$.

In total, $276.7 \mu \mathrm{g} / \mathrm{g}$ and $262.2 \mu \mathrm{g} / \mathrm{g}$ of polyphenolic compounds for the EtOAc and $\mathrm{MeOH}-\mathrm{H}_{2} \mathrm{O}$ extracts of $\mathrm{C}$. humilis, respectively, were attained. Such results are comparable with other Moroccan fruits, e.g., Ziziphus lotus, at least for the EtOAc extract $(298.5 \mu \mathrm{g} / \mathrm{g})[26]$. 
Table 7. Semi-quantification of polyphenols detected in C. humilis fruits in $\mu \mathrm{g} / \mathrm{g}(w / w)$.

\begin{tabular}{|c|c|c|c|}
\hline Compounds & EtOAc & $\mathrm{MeOH}-\mathrm{H}_{2} \mathrm{O}$ & $\begin{array}{l}\text { Standard Used for } \\
\text { Semi-Quantification }\end{array}$ \\
\hline \multicolumn{4}{|c|}{ Phenolic Acid and Derivatives } \\
\hline Quinic acid & $6.3 \pm 0.02$ & $37.0 \pm 0.36$ & Gallic acid \\
\hline Cinnamoyl glucose & $8.1 \pm 0.40$ & $0.3 \pm 0.03$ & Cinnamic acid \\
\hline Chlorogenic acid & $18.8 \pm 0.90$ & $45.4 \pm 1.59$ & Caffeic acid \\
\hline 3-Caffeoylquinic acid & $16.6 \pm 0.30$ & $22.4 \pm 0.14$ & Ferulic acid \\
\hline Feruloylquinic acid & $26.3 \pm 1.02$ & $12.4 \pm 0.07$ & Ferulic acid \\
\hline 5-Caffeoylquinic acid & $36.5 \pm 1.05$ & $20.3 \pm 0.62$ & Caffeic acid \\
\hline Ferulic acid hexoside & $12.9 \pm 0.82$ & $20.3 \pm 0.21$ & Ferulic acid \\
\hline p-coumaric acid & $11.3 \pm 0.50$ & $0.4 \pm 0.01$ & Coumarin \\
\hline Ferulic acid & $104.7 \pm 2.52$ & $20.6 \pm 0.9$ & Ferulic acid \\
\hline Dicaffeoylshikimic acid & $7.5 \pm 0.10$ & $10.1 \pm 0.5$ & Caffeic acid \\
\hline$p$-Coumaric acid ethyl ester & $12.7 \pm 0.12$ & - & Coumarin \\
\hline \multicolumn{4}{|c|}{ Flavonols } \\
\hline Rutin & $17.7 \pm 0.03$ & $60.2 \pm 1.9$ & Rutin \\
\hline Isorhamnetin-diglucoside & - & $12.8 \pm 0.8$ & Kaempferol \\
\hline Kaempferol & $15.0 \pm 0.93$ & - & Kaempferol \\
\hline
\end{tabular}

\section{Materials and Methods}

\subsection{Samples and Sample Extraction}

Chamaerops humilis L. fruits were harvested in Tangier-Tetouan-Al Hoceima, an area located in the extreme north-west of Morocco. The samples were collected for 4 months (May, June, July and August 2018). All of the harvest areas were between the longitudes $5^{\circ} 94^{\prime} 84106$ and the latitudes $35^{\circ} 44^{\prime} 701$. The fruit harvesting was carried out at their physiological maturity in the early morning, transported in well-closed boxes and stored at $-10{ }^{\circ} \mathrm{C}$ in the Materials and Resources Valorization Laboratory, Faculty of Sciences and Technology of Tangier. The extraction method employed was previously described by El Cadi et al. (2020) [26]. Briefly, $5 \mathrm{~g}$ of lyophilized powder underwent a defatting step by adding three times $50 \mathrm{~mL}$ of $n$-hexane; afterwards, it was dried and homogenized with $50 \mathrm{~mL}$ of two solvents with increased polarity, namely EtOAc and $\mathrm{MeOH}-\mathrm{H}_{2} \mathrm{O}$ 80:20 $(v / v)$. Each fraction was extracted by using an ultrasound bath $(130 \mathrm{kHz})$ for $45 \mathrm{~min}$. After centrifugation at $5000 \mathrm{~g}$ for $5 \mathrm{~min}$, the supernatant was filtered through a paper filter, dried, reconstituted with $\mathrm{MeOH}-\mathrm{H}_{2} \mathrm{O}$ and then filtered through a $0.45 \mu \mathrm{m}$ Acrodisc nylon membrane (Merck Life Science, Merck KGaA, Darmstadt, Germany) prior to HPLC-PDAESI/MS analysis.

\subsection{Chemical Reagents and Solvents}

Folin-Ciocalteu phenol reagent was obtained from Fluka. Standards (gallic acid, caffeic acid, cinnamic acid, ferulic acid, coumarin, rutin and kaempferol) were obtained from Merck Life Science (Merck KGaA, Darmstadt, Germany). In addition, 2,2-diphenyl-1picrylhydrazyl (DPPH) and butylated hydroxytoluene (BHT) were purchased from Sigma (St. Louis, MO, USA). LC-MS grade methanol, acetonitrile, acetic acid, EtOAc, acetone and water were purchased from Merck Life Science (Merck KGaA, Darmstadt, Germany). All of the other chemicals were of analytical grade and obtained from Sigma (St. Louis, MO, USA).

\subsection{Physico-Chemical Analyses and Phytochemical Screening}

Physico-chemical analyses and phytochemical screening were carried out according to a previously published work [26]. 


\subsection{Analysis and Quantification of Phenolic Contents}

TPP content was estimated using Folin-Ciocalteu method [35] and was expressed as mg of gallic acid (GAE)/g of dry mass (DM). TFv content was expressed as mg of quercetin (QE)/g of dry mass (DM) and quantified according to the method of Zhishen et al. [36]. TT content was determined by the vanillin method of Julkunen-Tiitto and expressed as $\mathrm{mg}$ (+)-catechin/g DW [37].

\subsection{Determination of Antioxidant Activity}

The DPPH method followed the method described by Braca et al. [38]. Butylated hydroxytoluene (BHT) was used as a positive control and the DPPH radical scavenging activity was calculated according to the equation:

$$
\text { DPPH radical scavenging activity: } I(\%)=(\text { A blank }- \text { A sample }) / \text { A blank } \times 100
$$

The $\mathrm{IC}_{50}$ of the $\mathrm{DPPH}$ radical was calculated from linear regression (\%DPPH remaining radical versus sample concentration).

\subsection{GC-MS}

GC analyses of the volatile fraction were performed on a GC-MS-QP2020 system (Shimadzu, Kyoto, Japan) with an "AOC-20i" system auto-injector. The analyses were realized on an SLB- $5 \mathrm{~ms}$ column (30 m in length $\times 0.25 \mathrm{~mm}$ in diameter $\times 0.25 \mu \mathrm{m}$ in thickness of film, Merck KGaA). The initial temperature was set at $50^{\circ} \mathrm{C}$, and afterwards increased up to $350^{\circ} \mathrm{C}$ (increase rate: $3^{\circ} \mathrm{C} / \mathrm{min}$; holding time: $5 \mathrm{~min}$ ).

GC-MS parameters were as follows: injection temperature: $280^{\circ} \mathrm{C}$; injection volume: $1.0 \mu \mathrm{L}$ (split ratio: 10:1); pure helium gas (99.9\%); linear velocity: $30.0 \mathrm{~cm} / \mathrm{s}$; inlet pressure: $26.7 \mathrm{KPa}$; EI source temperature: $220^{\circ} \mathrm{C}$; interface temperature: $250{ }^{\circ} \mathrm{C}$. The acquisition of MS spectra was realized in full scan mode, in the mass range of $40-660 \mathrm{~m} / \mathrm{z}$, with an event time of $0.2 \mathrm{~s}$.

Relative quantity of the chemical compounds present in each sample was expressed as a percentage based on peak area produced in the GC chromatogram.

Compounds were identified by using the "FFNSC 4.0" (Shimadzu Europa GmbH, Duisburg, Germany) and "W11N17" (Wiley11-Nist17, Wiley, Hoboken, NJ, USA; Mass Finder 3). Each compound was identified applying a MS similarity match and an LRI filter. Linear retention indices (LRI) were calculated by using a C7-C40 saturated alkanes reference mixture (49452-U, MerckKGaA).

Data files were collected and processed by using "GCMS Solution" software, ver. 4.50 (Shimadzu, Kyoto, Japan) [26].

\subsection{HPLC-PDA/ESI-MS}

LC analyses were performed on a Shimadzu liquid chromatography system (Kyoto, Japan), consisting of a CBM-20A controller, two LC-30AD dual-plunger parallel-flow pumps, a DGU-20A5R degasser, a CTO-20AC column oven, a SIL-30AC autosampler, an SPD-M30A photo diode array detector and an LCMS-8050 triple quadrupole mass spectrometer, through an ESI source (Shimadzu, Kyoto, Japan).

Chromatographic separations were attained on $150 \times 4.6 \mathrm{~mm} ; 2.7 \mu \mathrm{m}$ Ascentis Express RP C18 columns (Merck Life Science, Merck KGaA, Darmstadt, Germany). The mobile phase was composed of two solvents: water/acetic acid $(99.85 / 0.15 v / v$, solvent A) and acetonitrile/acetic acid $(99.85 / 0.15 \mathrm{v} / \mathrm{v}$, solvent $\mathrm{B})$. The flow rate was set at $1 \mathrm{~mL} / \mathrm{min}$ under gradient elution: 0-5 min, 5\% B, 5-15 min, 10\% B, 15-30 $\mathrm{min}, 20 \% \mathrm{~B}, 30-60 \mathrm{~min}, 50 \%$ B, $60 \mathrm{~min}, 100 \%$ B. PDA detection was: $\lambda=200-400 \mathrm{~nm}(\lambda=280 \mathrm{~nm}$ ) (sampling frequency: $40.0 \mathrm{~Hz}$, time constant: $0.08 \mathrm{~s}$ ). MS conditions were as follows: scan range and the scan speed were set at $m / z 100-800$ and $2500 \mathrm{amu} \mathrm{sec}^{-1}$, respectively, event time: $0.3 \mathrm{sec}$, nebulizing gas $\left(\mathrm{N}_{2}\right)$ flow rate: $1.5 \mathrm{~L} \mathrm{~min}^{-1}$, drying gas $\left(\mathrm{N}_{2}\right)$ flow rate: $15 \mathrm{~L} \mathrm{~min}^{-1}$, interface 
temperature: $350{ }^{\circ} \mathrm{C}$, heat block temperature: $300{ }^{\circ} \mathrm{C}$, DL (desolvation line) temperature: $300{ }^{\circ} \mathrm{C}$, DL voltage: $1 \mathrm{~V}$, interface voltage: $-4.5 \mathrm{kV}$ [26].

\subsection{Statistical Analysis}

The experiments were carried out in triplicate and the results were expressed as the average of the three measurements $\pm \mathrm{SD}$. The comparison of means between groups was performed with one-way analysis of variance (ANOVA) followed by a Tukey test. Differences were considered significant when $p<0.05$ (Microsoft ${ }^{\circledR}$ Office, Santa Rosa, California, CA, USA).

\section{Conclusions}

The present study aimed to elucidate the bioactive content of Chamaerops humilis L. fruits. Considering the two extracts tested, in terms of the antioxidant activity, the EtOAc one turned out to be the most active with respect to the $\mathrm{MeOH}-\mathrm{H}_{2} \mathrm{O}$. A total of 69 compounds belonging to different chemical classes were positively identified by GC coupled to MS, whereas sixteen and thirteen polyphenolic compounds were detected by HPLC-PDA/MS in both EtOAc and $\mathrm{MeOH}-\mathrm{H}_{2} \mathrm{O}$ extracts, respectively. Such results demonstrate that this fruit can be used for industrial applications in food preparations. In addition, the data attained emphasize an interesting functional composition of the Chamaerops humilis L. fruits, which could be considered a valuable new co-product with commercial importance in the food industry.

Author Contributions: Conceptualization, H.E.C. and F.C.; Methodology, H.E.C. and F.C.; Investigation, H.E.C.; H.E.B.; G.S.; B.R.; Y.O.E.M.; F.A.; and K.A.; Writing-Original Draft Preparation, H.E.C.; Writing-Review and Editing, F.C., M.P.L. and T.M.G.S.; Supervision, F.C. and J.B.; Project Administration: L.M. All authors have read and agreed to the published version of the manuscript.

Funding: This research received no external funding.

Institutional Review Board Statement: Not applicable.

Informed Consent Statement: Not applicable.

Data Availability Statement: Data sharing not applicable.

Acknowledgments: The authors thank Merck Life Science and Shimadzu Corporations for their continuous support.

Conflicts of Interest: The authors declare no conflict of interest.

Sample Availability: Samples of the compounds are not available from the authors.

\section{References}

1. Tassin, C. Paysages Végétaux du Domaine Méditerranéen: Bassin Méditerranéen, Californie, Chili Central, Afrique du Sud, Australie Méridionale; IRD Éditions: Marseille, France, 2012.

2. Bouhafsoun, A.; Boukeloua, A.; Yener, I.; Diare Mohamed, L.; Diarra, T.; Errouane, K.; Mezmaz, R.; Temel, H.; Kaid-Harche, M. Chemical composition and mineral contents of leaflets, rachs and fruits of Chamaerops humilis L. Acad. J. Agric. Res. 2019, $20,8$.

3. Nehdi, I.A.; Mokbli, S.; Sbihi, H.; Tan, C.P.; Al-Resayes, S.I. Chamaerops humilis L. var. argentea André Date Palm Seed Oil: A Potential Dietetic Plant Product: Nutritional value of C. humilis seed oil. J. Food Sci. 2014, 79, C534-C539. [CrossRef] [PubMed]

4. Bnouham, M.; Merhfour, F.Z.; Ziyyat, A.; Aziz, M.; Legssyer, A.; Mekhfi, H. Antidiabetic effect of some medicinal plants of Oriental Morocco in neonatal non-insulin-dependent diabetes mellitus rats. Hum. Exp. Toxicol. 2010, 29, 865-871. [CrossRef]

5. Hasnaoui, O.; Bouazza, M.; Benali, O.; Thinon, M. Ethno Botanic Study of Chamaerops humilis L. Var. argentea Andre (Are-caceae) in Western Algeria. Agric. J. 2011, 6, 1-6.

6. Gaamoussi, F.; Israili, Z.H.; Lyoussi, B. Hypoglycemic and hypolipidemic effects of an aqueous extract of Chamaerops humilis leaves in obese, hyperglycemic and hyperlipidemic Meriones shawi rats. Pak. J. Pharm. Sci. 2010, 23, 212-219. [PubMed]

7. Benmehdi, H.; Hasnaoui, O.; Benali, O.; Salhi, F. Phytochemical investigation of leaves and fruits extracts of Chamaerops humilis L. J. Mater. Environ. Sci. 2012, 3, 320-337.

8. Blumenthal, M.; Busse, W.; Goldberg, A.; Gruenwald, J.; Hall, T.; Riggins, C.W.; Rister, R.S. The Complete German Commis-sion E Monographs: Therapeutic Guide to Herbal Medicines; American Botanical Council: Austin, TX, USA; Integrative Medicine Communications: Boston, MA, USA, 1998. 
9. Benahmed-Bouhafsoun, A.; Djied, S.; Mouzaz, F.; Kaid-Harche, M. Phytochemical composition and in vitro antioxidant activity of Chamaerops humilis L. extracts. Int. J. Pharm. Pharm. Sci. 2013, 5, 741-744.

10. Miguel, M.; Bouchmaaa, N.; Aazza, S.; Gaamoussi, F.; Lyoussi, B. Antioxidant, anti-inflammatory and anti-acetylcholinesterase activities of Moroccan plants. Fresenius Environ. Bull. 2014, 23, 1-14.

11. Fekar, G.; Aiboudi, M.; Bouyazza, L. Composition en acides gras, stérols et tocophérols de 1 huile végétale non convention-nelle extraite des graines du Chamaerops humilis L. du Maroc. Afrique Sci. 2015, 11, 6.

12. Gonçalves, S.; Medronho, J.; Moreira, E.; Grosso, C.; Andrade, P.B.; Valentão, P.; Romano, A. Bioactive properties of Chamaerops humilis L.: Antioxidant and enzyme inhibiting activities of extracts from leaves, seeds, pulp and peel. 3 Biotech 2018, 8, 88. [CrossRef]

13. Ferrão, T.S.; Ferreira, D.F.; Flores, D.W.; Bernardi, G.; Link, D.; Barin, J.S.; Wagner, R. Evaluation of composition and quality parameters of jelly palm (Butia odorata) fruits from different regions of Southern Brazil. Food Res. Int. 2013, 54, 57-62. [CrossRef]

14. FAO. Street Foods: A Summary of FAO Studies and Other Activities Relating to Street Foods; Food and Agriculture Organization of the United States: Rome, Italy, 1988.

15. Shaba, E.Y.; Ndamitso, M.M.; Mathew, J.T.; Etsunyakpa, M.B.; Tsado, A.N.; Muhammad, S.S. Nutritional and anti-nutritional composition of date palm (Phoenix dactylifera L.) fruits sold in major markets of Minna Niger State, Nigeria. Afr. J. Pure Appl. Chem. 2015, 9, 167-174.

16. Aamer, R.A. Characteristics of aqueous doum fruit extract and its utilization in some novel products. Ann. Agric. Sci. 2016, 61, 25-33. [CrossRef]

17. Beskow, G.T.; Hoffmann, J.F.; Teixeira, A.M.; Fachinello, J.C.; Chaves, F.C.; Rombaldi, C.V. Bioactive and yield potential of jelly palms (Butia odorata Barb. Rodr.). Food Chem. 2015, 172, 699-704. [CrossRef]

18. Carvalho Filho, C.D.; Honório, S.L.; Gil, J.M. Qualidade pós-colheita de cerejas cv. Ambrunés utilizando coberturas comestíveis. Rev. Bras. Frutic. 2006, 28, 180-184. [CrossRef]

19. Chitarra, M.I.F.; Chitarra, A.B. Pós-Colheita de Frutos e Hortaliças: Fisiologia e, Pós-colheita de Frutos e Hortaliças: Fisiologia e Manuseio, 1st ed.; Federal University of Lavras: Lavras, Brazil, 1990.

20. Schwartz, E.; Fachinello, J.C.; Barbieri, R.L.; da Silva, J.B. Avaliação de populações de Butia capitata de Santa Vitória do Palmar. Rev. Bras. Frutic. 2010, 32, 736-745. [CrossRef]

21. Santas, J.; Carbó, R.; Gordon, M.; Almajano, M. Comparison of the antioxidant activity of two Spanish onion varieties. Food Chem. 2008, 107, 1210-1216. [CrossRef]

22. Lv, S.; Taha, A.; Hu, H.; Lu, Q.; Pan, S. Effects of Ultrasonic-Assisted Extraction on the Physicochemical Properties of Different Walnut Proteins. Molecules 2019, 24, 4260. [CrossRef]

23. Bouhafsoun, A.; Yilmaz, M.A.; Boukeloua, A.; Temel, H.; Harche, M.K. Simultaneous quantification of phenolic acids and flavonoids in Chamaerops humilis L. using LC-ESI-MS/MS. Food Sci. Technol. 2018, 38, 242-247. [CrossRef]

24. Estrada, A.; Katselis, G.S.; Laarveld, B.; Barl, B. Isolation and evaluation of immunological adjuvant activities of saponins from Polygala senega L. Comp. Immunol. Microbiol. Infect. Dis. 2000, 23, 27-43. [CrossRef]

25. Just, M.J.; Recio, M.C.; Giner, R.M.; Cuéllar, M.J.; Máñez, S.; Bilia, A.R.; Ríos, J.-L. Anti-Inflammatory Activity of Unusual Lupane Saponins from Bupleurum fruticescens. Planta Med. 1998, 64, 404-407. [CrossRef] [PubMed]

26. El Cadi, H.; El Bouzidi, H.; Selama, G.; El Cadi, A.; Ramdan, B.; Oulad El Majdoub, Y.; Alibrando, F.; Dugo, P.; Mondello, L.; Fakih Lanjri, A.; et al. Physico-Chemical and Phytochemical Characterization of Moroccan Wild Jujube "Zizyphus lotus (L.)" Fruit Crude Extract and Fractions. Molecules 2020, 25, 5237. [CrossRef] [PubMed]

27. Belhaoues, S.; Amri, S.; Bensouilah, M.; Seridi, R. Antioxidant, antibacterial activities and phenolic content of organic frac-tions obtained from Chamaerops humilis L. leaf and fruit. Int. J. Biosci. 2017, 11, 284-297.

28. Khoudali, S.; Benmessaoudleft, D.; Essaqui, A.; Zertoubi, M.; Mohammed, A.; Benaissa, B. Study of antioxidant activity and anticorrosion action of the methanol extract of dwarf palm leaves (Chamaerops humilis L.) from morocco. J. Mater. Environ. Sci. 2014, 5, 887-898.

29. Coelho, J.P.; Veiga, J.G.; Elvas-Leitao, R.; Brigas, A.F.; Dias, A.M.; Oliveira, M.C. Composition and in vitro antioxidants ac-tivity of Chamaerops humilis L. In Proceedings of the 2017 IEEE 5th Portuguese Meeting on Bioengineering (ENBENG), Coimbra, Portugal, 16-18 February 2017; pp. 1-4.

30. Chung-Weng, P.; Abd Malek, S.N.; Ibrahim, H.; Wahab, N.A. Antioxidant properties of crude and fractionated extracts of Alpinia mutica rhizomes and their total phenolic content. Afr. J. Pharm. Pharmacol. 2011, 5, 842-852.

31. Mokbli, S.; Sbihi, H.M.; Nehdi, I.A.; Romdhani-Younes, M.; Tan, C.P.; Al-Resayes, S.I. Characteristics of Chamaerops humilis L. var. humilis seed oil and study of the oxidative stability by blending with soybean oil. J. Food Sci. Technol. 2018, 55, $2170-2179$. [CrossRef]

32. Giovino, A.; Marino, P.; Domina, G.; Rapisarda, P.; Rizza, G.; Saia, S. Fatty acid composition of the seed lipids of Chamaerops humilis L. natural populations and its relation with the environment. Plant Biosyst. Int. J. Deal. All Asp. Plant Biol. 2014, 149, 767-776. [CrossRef]

33. Khallouki, F.; Ricarte, I.; Breuer, A.; Owen, R.W. Characterization of phenolic compounds in mature Moroccan Medjool date palm fruits (Phoenix dactylifera) by HPLC-PDA-ESI-MS. J. Food Comp. Anal. 2018, 70, 63-71. [CrossRef]

34. Ma, C.; Dunshea, F.R.; Suleria, H.A.R. LC-ESI-QTOF/MS Characterization of Phenolic Compounds in Palm Fruits (Jelly and Fishtail Palm) and Their Potential Antioxidant Activities. Antioxidants 2019, 8, 483. [CrossRef] 
35. Singleton, V.; Rossi, J. Colorimetry of Total Phenolic Compounds with Phosphomolybdic-Phosphotungstic Acid Reagents. Am. J. Enol. Vitic. 1965, 16, 144-158.

36. Zhishen, J.; Mengcheng, T.; Jianming, W. The determination of flavonoid contents in mulberry and their scavenging effects on superoxide radicals. Food Chem. 1999, 64, 555-559. [CrossRef]

37. Julkunen-Tiitto, R. Phenolic constituents in the leaves of northern willows: Methods for the analysis of certain phenolics. J. Agric. Food Chem. 1985, 33, 213-217. [CrossRef]

38. Braca, A.; Sortino, C.; Politi, M.; Morelli, I.; Mendez, J. Antioxidant activity of flavonoids from Licania licaniaeflora. J. Ethnopharmacol. 2002, 79, 379-381. [CrossRef] 